University of Nebraska - Lincoln

DigitalCommons@University of Nebraska - Lincoln

Faculty Publications in the Biological Sciences

Papers in the Biological Sciences

1998

\title{
Population biology of intraspecific polyploidy in grasses
}

Kathleen H. Keeler

University of Nebraska - Lincoln, kkeeler1@unl.edu

Follow this and additional works at: https://digitalcommons.unl.edu/bioscifacpub

Part of the Botany Commons, Plant Biology Commons, and the Population Biology Commons

Keeler, Kathleen H., "Population biology of intraspecific polyploidy in grasses" (1998). Faculty Publications in the Biological Sciences. 296.

https://digitalcommons.unl.edu/bioscifacpub/296

This Article is brought to you for free and open access by the Papers in the Biological Sciences at DigitalCommons@University of Nebraska - Lincoln. It has been accepted for inclusion in Faculty Publications in the Biological Sciences by an authorized administrator of DigitalCommons@University of Nebraska - Lincoln. 


\title{
Population biology of intraspecific polyploidy in grasses
}

\author{
KATHLEEN H. KEELER
}

Polyploidy is the duplication of an entire nuclear genome, whether diploid or higher level (Stebbins, 1971; Thompson \& Lumaret, 1992) and a frequent occurrence in plants. Stebbins (1971) estimated that 30-35\% of flowering plant species are polyploid, and that many more had a polyploid event in their evolutionary history, including all members of such important families as the Magnoliaceae, Salicaceae, and Ericaceae. Goldblatt (1980) estimated $55 \%$, but probably up to $75 \%$, of monocotyledons had at least one polyploid event in their history, using the criterion that if the species has a base number higher than $n=13$ it is derived from a polyploid. Using the same criterion, Grant (1981) estimated that $52 \%$ of angiosperms, $49 \%$ of dicotyledon species and $60 \%$ of monocotyledons are polyploid. Masterson (1994) supports high frequencies of ancestral polyploidy using fossil evidence. Clearly, polyploids have been fixed in many lineages.

Within many genera of higher plants, individual species often have different, but uniform, ploidy levels (e.g. Draba, Brassicaceae, Brockman \& Elven, 1992), the grasses being no exception, e.g. Bromus, Elymus (Seberg \& von Bothmer, 1991; Ainouche, Misset \& Huon, 1995). Intrageneric polyploid series provide another indicator of frequent polyploid events. For example, of a miscellaneous collection of 87 grass genera for which I had chromosome numbers for two or more species, $65(75 \%)$ formed a polyploid series in relation to other members of the genus (Table 7.1).

Stebbins (1947) distinguished the forms of polyploidy based on whether the duplicated genomes are derived from one species (autopolyploidy) or two (allopolyploidy) or both (segmental allopolyploidy). Recent detailed genetic analysis has made it possible to distinguish these based on homology of the genomes: the same genomes in multiple copies (autopolyploidy), or several different genomes in the same individual (allopolyploidy) (Jackson, 1982). 
Table 7.1. Polyploid series within some grass genera

Plants entered only if cytotype is available for two or more species. Taxonomy is that of the author and not necessarily modern.

\begin{tabular}{|c|c|c|}
\hline \multirow{2}{*}{$\frac{\text { Genus }}{\text { Aegilops }}$} & \multicolumn{2}{|l|}{ Cytotypes of selected members } \\
\hline & 28,56 & Hickman, 1993 \\
\hline Agropyron & $14,28,42,56$ & Bowden, 1965 \\
\hline Agrostis & $14,28,42,56$ & Bowden, 1965; Hickman, 1993 \\
\hline Aira & 14,28 & Myers, 1947 \\
\hline Alopecurus & $14,28,56,70,98,112-116$ & Myers, 1947 \\
\hline Ammophila & 28 & Myers, 1947 \\
\hline Andropogon & $\begin{array}{l}20,30,40,45,50,60,80,120 \\
\quad 180\end{array}$ & $\begin{array}{l}\text { Myers, 1947; Norrmann } \\
\text { \& Quarín, } 1987\end{array}$ \\
\hline Anthoxanthum & $10,20,80$ & Myers, 1947; Hedberg, 1967 \\
\hline Aristida & 22,44 & Hickman, 1993 \\
\hline Arrhenatherum & 28,40 & Myers, 1947 \\
\hline Arthraxon & 36 & Myers, 1947 \\
\hline Arundinaria & 48,54 & Myers, 1947 \\
\hline Avena & $14,28,42$ & Hickman, 1993 \\
\hline Bambusa & 68,72 & Myers, 1947 \\
\hline Bouteloua & $20,21,22,35,40,42$ & Myers, 1947 \\
\hline Brachypodium & 14,18 & Myers, 1947 \\
\hline Briza & 10,14 & Myers, 1947 \\
\hline Bromus & $14,28,42,56,70$ & $\begin{array}{l}\text { Myers, 1947; Sutherland, } \\
\text { 1986; Ainouche } \text { et al., } 1995\end{array}$ \\
\hline Calamagrostis & $28,42,56,79,84$ & Myers, 1947; Sutherland, 1986 \\
\hline Calamovilfa & 40 & Sutherland, 1986 \\
\hline Catabrossa & 20 & Sutherland, 1986 \\
\hline Cenchrus & 34,70 & Myers, 1947; Sutherland, 1986 \\
\hline Chimonobambusa & 48 & Myers, 1947 \\
\hline Chloris & $20,30,40,50,80$ & Myers, 1947 \\
\hline Cinna & 28 & Myers, 1947 \\
\hline Coix & 10,20 & Myers, 1947 \\
\hline Cymbopogon & 20,40 & Myers, 1947 \\
\hline Cynodon & $18,36,54$ & Sutherland, 1986 \\
\hline Cynosurus & 14 & Myers, 1947 \\
\hline Dactylis & $14,28,42$ & Lumaret, $1988 b$ \\
\hline Dactylocteniaum & 34,48 & Myers, 1947 \\
\hline Danthonia & $18,24,36,42,48$ & Myers, 1947; Hickman, 1993 \\
\hline Deschampsia & $14,26,28,42$ & $\begin{array}{l}\text { Myers, 1947; Rothera \& Davy, } \\
1986\end{array}$ \\
\hline Dichanthelium & 18 & Sutherland, 1988 \\
\hline Digitaria & $16,24,28,30,36,54,72$ & Myers, 1947; Sutherland, 1986 \\
\hline Distichlis & 40 & Myers, 1947 \\
\hline Echinochloa & $36,54,130$ & Myers, 1947; Sutherland, 1986 \\
\hline Ehrharta & 24,48 & Myers, 1947 \\
\hline Eleusine & $18,36,45$ & Myers, 1947 \\
\hline Elymus & $14,28,42,56$ & Myers, 1947 \\
\hline Eragrostis & $20,40,42,50,60,80,100,120$ & Myers, 1947; Sutherland, 1986 \\
\hline Erianthus & 20,60 & Myers, 1947 \\
\hline Euchlaena & 20,40 & Myers, 1947 \\
\hline Festuca & $14,28,42,56,63,70$ & Seal, 1983 \\
\hline Gastridium & 14,28 & Myers, 1947 \\
\hline
\end{tabular}


Table 7.1. (cont.)

Plants entered only if cytotype is available for two or more species. Taxonomy is that of the author and not necessarily modern.

\begin{tabular}{|c|c|c|}
\hline \multirow{2}{*}{$\frac{\text { Genus }}{\text { Glyceria }}$} & \multicolumn{2}{|l|}{ Cytotypes of selected members } \\
\hline & $10,14,20,28,40,56$ & Myers, 1947; Hickman, 1993 \\
\hline Hilaria & 18,36 & Sutherland, 1986 \\
\hline Holcus & 14,28 & $\begin{array}{l}\text { Jones, 1958; Richard et al., } \\
\quad 1995\end{array}$ \\
\hline Hordeum & $14,28,42$ & $\begin{array}{l}\text { von Bothmer \& Jacobsen, } \\
\text { 1986; Kankanpää et al, } 1996\end{array}$ \\
\hline Hystrix & 28,56 & Myers, 1947 \\
\hline Koeleria & 14,28 & Myers, 1947 \\
\hline Leersia & 48,96 & Myers, 1947 \\
\hline Leptochloa & 20,40 & Sutherland, 1986 \\
\hline Lepturus & $14,26,36$ & Myers, 1947 \\
\hline Lolium & 14,28 & Sutherland, 1986 \\
\hline Melica & 18 & Myers, 1947 \\
\hline Milium & 18,28 & Myers, 1947 \\
\hline Miscanthus & $36,42,64$ & Myers, 1947 \\
\hline Muhlenbergia & $18,20,40,42,60,80$ & Myers, 1947; Hickman, 1993 \\
\hline Munroa & 16 & Sutherland, 1947 \\
\hline Oplismenus & 54,72 & Myers, 1947 \\
\hline Oryza & 24,48 & Myers, 1947 \\
\hline Oryzopsis & $22,24,46,48$ & Sutherland, 1988 \\
\hline Panicum & $18,20,36,40,54,72,90,108$ & Myers, 1947; Sutherland, 1986 \\
\hline Paspalum & $\begin{array}{l}20,25,40,45,55,60,80,120 \\
160\end{array}$ & $\begin{array}{l}\text { Burton, 1942; Myers, 1947; } \\
\quad \text { Quarin et al., } 1982\end{array}$ \\
\hline Pennisetum & $14,27,28,36,45,54$ & Burton, 1942 \\
\hline Phalaris & $12,14,28,42$ & Myers, 1947 \\
\hline Phippsia & 28 & Myers, 1947 \\
\hline Phleioblastus & 48 & Myers, 1947 \\
\hline Phleum & $14,28,42$ & Myers, 1947 \\
\hline Phyllostachys & 48,54 & Myers, 1947 \\
\hline Poa & $\begin{array}{l}14,28,35,42,54,56,62,64 \\
\quad 70,76,84,106\end{array}$ & Myers, 1947; Sutherland, 1986 \\
\hline Polypogon & $14,28,42$ & Hickman, 1993 \\
\hline Puccinellia & $14,28,42,56$ & Myers, 1947; Sutherland, 1986 \\
\hline Saccharum & $40,80,112$ & Myers, 1947 \\
\hline Sasa & 48 & Myers, 1947 \\
\hline Setaria & $18,36,54,72$ & Sutherland, 1986 \\
\hline Sitanion & 28 & Myers, 1947 \\
\hline Sorghastrum & 20,40 & Myers, 1947 \\
\hline Sorghum & $10,20,40$ & Gu et al., 1984 \\
\hline Spartina & $28,40,42,56,80,84,112,128$ & Myers, 1947; Hickman, 1993 \\
\hline Sporobolus & $\begin{array}{l}18,24,36,45,46,54,72,82 \\
108\end{array}$ & Sutherland, 1986 \\
\hline Stipa & $\begin{array}{l}24,28,34,36,40,42,44,46 \\
\quad 48,64,68,70,82\end{array}$ & Myers, 1947 \\
\hline Tridens & $16,32,40,60$ & Sutherland, 1986 \\
\hline Triodia & 28,48 & Myers, 1947 \\
\hline Trisetum & $14,24,26,28,42$ & Myers, 1947 \\
\hline Zizania & 30 & Myers, 1947 \\
\hline
\end{tabular}


In many taxa the current genome is a complex product of multiple occurrences of both allo- and autopolyploidy. Allopolyploids begin with a hybrid. The doubling of the two genomes solves pairing problems between its component genomes. Sometimes doubling occurs after the production of a relatively sterile hybrid (e.g. Spartina anglica, Guenegou, Citharel \& Levasseur, 1988), sometimes allopolyploidy is the result of direct combination of unreduced gametes (Bretagnolle \& Thompson, 1995). Allopolyploidy can occur multiple times in the history of a species as in Triticum aestivum (Sears, 1969). Autopolyploidy occurs when, within a single lineage, the genome duplicates, usually by production of an unreduced gamete that successfully forms an embryo, either combined with a normal (reduced) gamete or another unreduced gamete (Bretagnolle \& Thompson, 1995). Historically, more attention has been paid to allopolyploidy than autopolyploidy and it has been considered to be by far the most important form of polyploidy (Stebbins, 1971; Grant, 1981). Recent work, however, finds autopolyploidy to be relatively common (Thompson \& Lumaret, 1992; Bretagnolle \& Thompson, 1995).

Stebbins $(1947,1971)$ proposed a widely accepted sequence for the development of polyploidy within lineages. First tetraploidy occurs, then the tetraploids spread and replace the diploids. The diploids become geographically restricted, rare, and then extinct, and the process repeats as hexaploids and octoploids are formed from the tetraploids and expand at the expense of the tetraploids. Although Stebbins considered autopolyploidy rare, the model needs little modification to incorporate autopolyploidy.

In an allopolyploid complex, when the ploidy levels are incompatible, there is a tight relationship between ploidy level and taxonomy, i.e. different ploidy levels belong in different species. Such polyploid series occur in many grass genera (Table 7.1). Although it has not been studied, polyploid series within genera should also result from autopolyploids becoming fixed in one derived species, but not in another. During this process, populations containing a mixture of ploidy levels might persist for long periods of time. Indeed, it appears that derived species may carry intraspecific polyploid variation with them, as in the case of Andropogon hallii, which is clearly derived from $A$. gerardii, and has similar intraspecific polyploidy (Sutherland, 1986; Table 7.3). In these cases ploidy level need not correlate with taxonomic divisions (see below). Little is known about the relative frequency of these processes.

This paper discusses polyploidy within species of grasses. For more general reviews of polyploidy, see Stebbins (1971), Lewis (1980), Grant (1981), Lumaret (1988a), and Thompson \& Lumaret (1992). 


\section{Distribution of intraspecific polyploidy}

Species that are composed of individuals and populations with differing ploidy levels are known from many families, including the Chenopodiaceae (Dunford, 1985; Freeman \& McArthur, 1989), Fabaceae (Grant, Brown \& Grace, 1984; Hymowitz, Parker \& Singh, 1991), Rosaceae (Campbell, Greene \& Bergquist, 1987), reviewed in Lewis (1980).

Variation in ploidy level occurs within many grass species (Federov, 1974; Lewis, 1980; Keeler \& Kwankin, 1989; Table 7.2). Of the grass species listed in the floras of the Great Plains (Sutherland, 1986) and California (Hickman, 1993) about 21\% of the species were reported to have intraspecific polyploidy (Table 7.3). It is difficult to evaluate the quality of this value: (a) Some old counts produced with untrustworthy methods are probably still being cited (see discussion in Church, 1936). (b) With higher numbers of chromosomes, accurate counting is more difficult and so less accurate. (c) Some reports of intraspecific polyploidy may be the result of taxonomic confusion: certainly taxonomic revision can greatly simplify the cytogenetics of some genera. (d) On the other hand, for some species, the cytotype is known from a single count, therefore it is not known whether the species is chromosomally variable. (e) Other species are only very sketchily sampled or from only part of an extensive range, likewise making undetected intraspecific polyploidy possible. I think it is premature to analyse patterns of intraspecific polyploidy within the Poaceae, although it is obvious that a substantial number of species have been reported to possess intraspecific polyploidy.

\section{Genetics of polyploids}

Polyploidy usually produces profound changes in the genetics of the species. These changes can include change in Mendelian inheritance patterns and modification of dominance relationships, declines in fertility, loss of incompatibility, greater retention of genetic diversity under selfing and loss of interfertility with other members of the (former) species (Haldane, 1930; Mather, 1936; Fisher, 1949; Levin, 1983; Fowler \& Levin, 1984; reviewed in Bever \& Felber, 1993). There is a rich literature on the genetics of polyploids of agricultural importance, such as Solanum and Triticum (e.g. Simmonds, 1976; Tsuchiye \& Gupta, 1991). Theoretical studies of polyploid genetics go back 60 years (Haldane, 1930; Mather, 1936), and there is a growing body of more recent population genetics theory (Ehlke \& Hill, 1988; Bever \& Felber, 1993, Rodríguez, 1996a,b). Only a brief review relevant to intraspecific polyploid variation will be given here. 


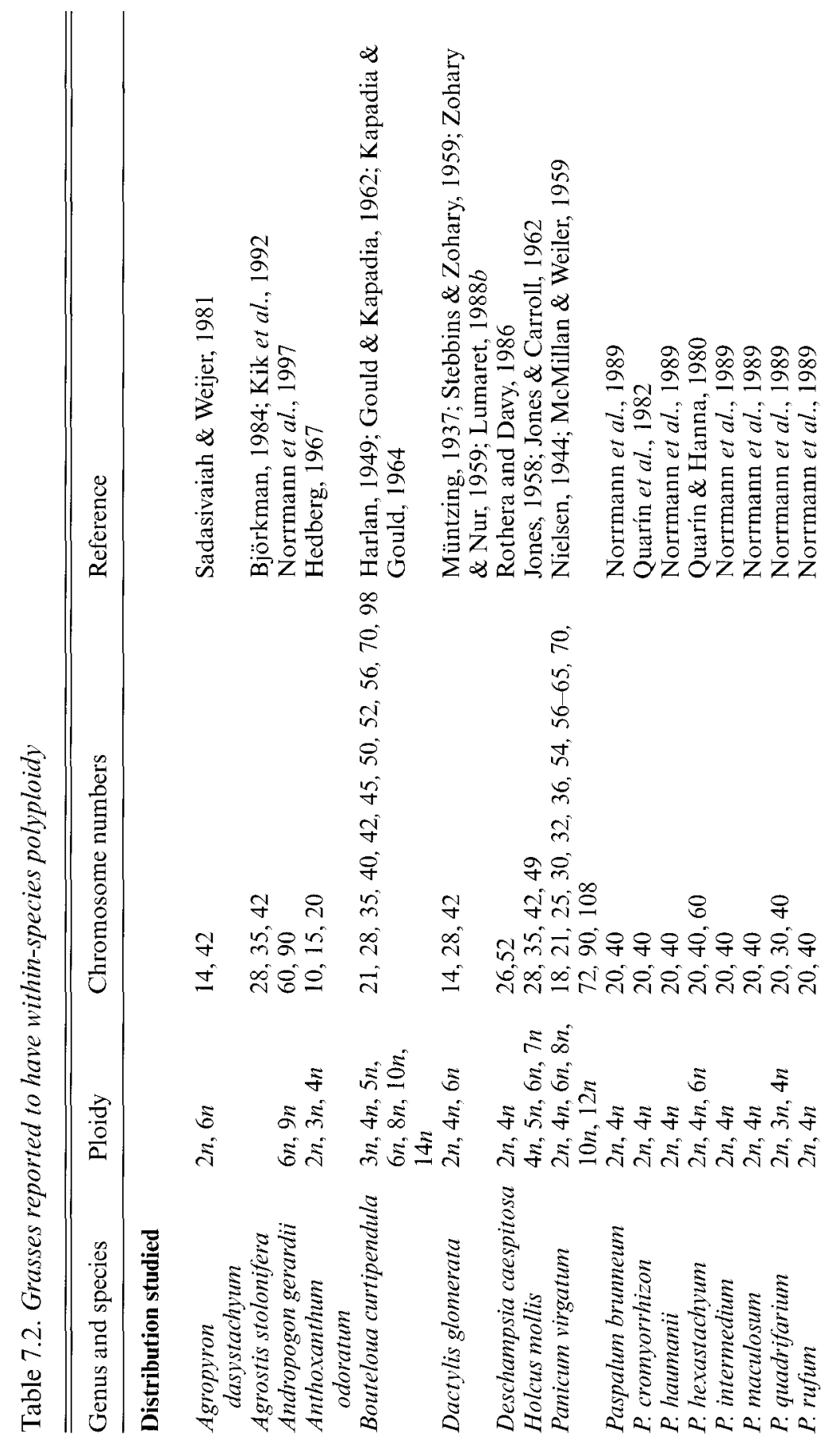




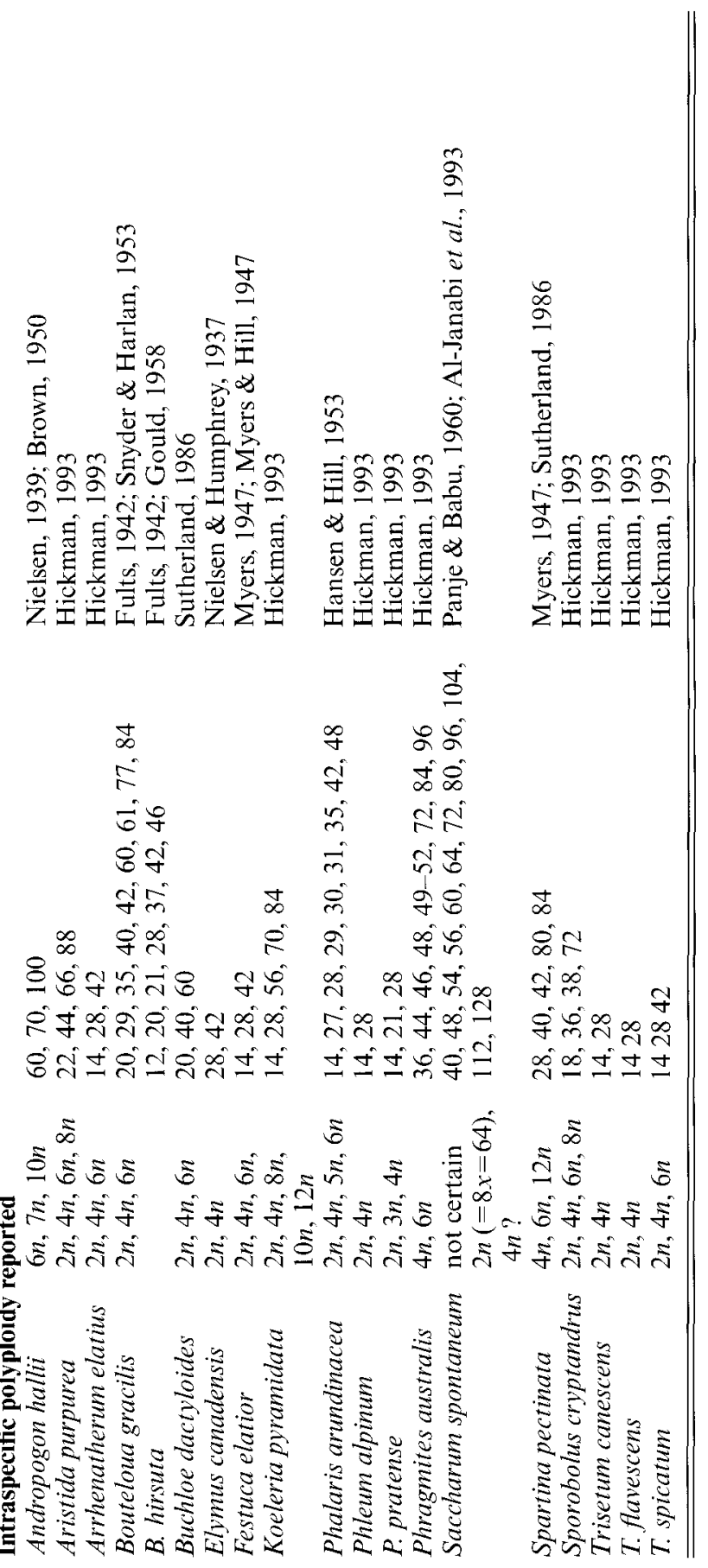


Table 7.3. Frequency of grass species with intraspecific polyploidy in two recent floras

\begin{tabular}{|c|c|c|c|c|c|}
\hline Flora & $\begin{array}{l}\text { Intraspecific } \\
\text { polyploid } \\
\text { series } \\
\text { reported }\end{array}$ & $\begin{array}{l}\text { One } \\
\text { chromosome } \\
\text { number in } \\
\text { the species }\end{array}$ & $\begin{array}{l}\text { Variation } \\
\text { but not a } \\
\text { polyploid } \\
\text { series }\end{array}$ & $\begin{array}{l}\text { No value } \\
\text { reported }\end{array}$ & $\begin{array}{l}\text { Total grass } \\
\text { species }\end{array}$ \\
\hline Great Plains & $84(33.5 \%)$ & $127(50.6 \%)$ & $19(7.6 \%)$ & $21(8.4 \%)$ & 251 \\
\hline California & $82(16.6 \%)$ & $307(62.0 \%)$ & $34(6.9 \%)$ & $72(14.5 \%)$ & 495 \\
\hline Shared species & 27 & 45 & 6 & 0 & 78 \\
\hline Combined & $138(20.7 \%)$ & $390(58.4 \%)$ & $47(7.0 \%)$ & $93(13.9 \%)$ & 668 \\
\hline
\end{tabular}

Note:

Taken from Sutherland (1986); Hickman (1993).

For ease of description I will outline the differences using diploids and tetraploids. Diploids are the basis on normal Mendelian genetics: each individual has two copies of each (non-duplicated) locus, and so can be heterozygous $\left(a_{1} a_{2}\right)$ or homozygous $\left(a_{1} a_{1}\right.$, or $\left.a_{2} a_{2}\right)$. If there is dominance, the heterozygote shows some phenotype other than one intermediate between the homozygotes. Under selfing, diploids approach two pure lines rapidly: half of the progeny are expected to be homozygotes and so frequency of heterozygotes drops by $50 \%$ each generation. Progeny receive just one of the two alleles of each parent.

In contrast, tetraploids have four copies of each locus, and normal terminology for heterozygosity immediately breaks down. While homozygous tetraploids are clear: $a_{1} a_{1} a_{1} a_{1}$ and $a_{2} a_{2} a_{2} a_{2}$, heterozygotes could be $a_{1} a_{1} a_{1} a_{2}$, $\mathrm{a}_{1} \mathrm{a}_{1} \mathrm{a}_{2} \mathrm{a}_{2}$ and $\mathrm{a}_{1} \mathrm{a}_{2} \mathrm{a}_{2} \mathrm{a}_{2}$. But of course they are not limited to just two alleles per individual the way diploids are, so additional forms of heterozygosity exist, to the extreme of $a_{1} a_{2} a_{3} a_{4}$. Dominance between the alleles is not per se affected by ploidy levels, but since so many more alleles can occur in the same individual, that dominant allele may mask a greater variety of different genetic combinations. In addition, the phenotypes produced by interactions between co-occurring alleles are far more complicated $\left(a_{1} a_{1} a_{2} a_{3}\right.$ might be functionally distinguishable from $a_{1} a_{2} a_{2} a_{3}$ and $a_{1} a_{2} a_{3} a_{3}$ ). At the enzyme level, being tetraploid opens up the possibility for a wide array of dimeric enzymes produced by combinations of two allele products. Under selfing, a much lower percentage of the progeny will be homozygotes. Assume for simplicity we start with $\mathrm{a}_{1} \mathrm{a}_{1} \mathrm{a}_{2} \mathrm{a}_{2}$, selfed: $17 \%$ of the progeny will be homozygotes, so that $83 \%$ of the genetic variation is retained. After five generations, when $97 \%$ of the diploid population would 
be expected to be homozygous under selfing $\left(0.5^{5}\right), 60.6 \%$ of the tetraploid population will be homozygous $\left(0.83^{5}\right)$, a much slower loss of genetic variation (Haldane, 1930). Finally, progeny receive two copies of the genome from each parent. This is more complex than it seems, because at meiosis, crossing over can recombine the alleles with respect to the centromere. Genetic exchange among the two chromosomes of diploids breaks up linkage groups. In tetraploids, since crossing over and segregation can result in double reduction, the same allele being twice included in a gamete, it is therefore possible for $\mathrm{a}_{1} \mathrm{a}_{2} \mathrm{a}_{2} \mathrm{a}_{2}$, selfed, to produce among its progeny $\mathrm{a}_{1} \mathrm{a}_{1} \mathrm{a}_{2} \mathrm{a}_{2}$. In some cases the frequency of double reduction could be $50 \%$ (Mather, 1936). Thus the genetic recombination of tetraploids is more than just a simple doubling of all the values of the diploid: much more variation is possible. For more detail see the review by Bever \& Felber (1993).

The comments made for tetraploids relative to diploids apply likewise to hexaploids and octoploids and other higher multiples (summarized by Bever \& Felber, 1993). The variety possible is a geometric, not linear, expansion.

One of the key observations about polyploidy is that where there is not strict control of meiotic segregation, there is significant loss of fitness due to production of gametes with incomplete or partially duplicated genomes. In addition, segregation in polyploids that are odd multiples of the basic number, i.e. triploids $(3 n)$, pentaploids $(5 n)$, etc., often results in gametes receiving partial genomes and, therefore, chromosome complements that function poorly or not at all. There is widespread documentation of reduced fertility of these odd-numbered ploidy levels although the situation is complex and species differ greatly (Stebbins, 1971; Grant 1981).

Chromosome combinations which produce few viable gametes are important in understanding the evolution of polyploidy because chromosome complements and crosses that result in unbalanced gametes are usually at a fitness disadvantage compared with conspecifics with even multiples of the genome. Where polyploidy confers an obvious decrease in fitness, it is clear that doubling the genome is not a neutral trait, and an explanation for maintenance or recurrent origin of the polyploids is required.

As emphasized by Bever \& Felber (1993) much more work remains to be done on the genetics and population genetics of polyploids.

\section{Implications of intraspecific polyploidy}

Intraspecific polyploidy is not necessarily a result of poor taxonomy. Disparate ploidy levels are frequently both interfertile and morphologically 
indistinguishable: the evolutionary unit in many grass species is a population of plants of diverse ploidy levels. Although historically plants with different ploidy levels have been held to be reproductively isolated from each other, this has proven to be an oversimplification.

First, gene flow can occur between ploidy levels. Dactylis glomerata and Andropogon gerardii, both autopolyploid complexes, show interploidy level fertility (i.e. gene flow) (Zohary \& Nur, 1959; Lumaret, 1988b; Norrmann, Quarín \& Keeler, 1997). In Holcus, allopentaploids produce fertile diploid progeny (Richard et al., 1995).

In general, fertility is greater in even multiples of the genome, and intraploidy level hybrids such as triploids and pentaploids are of significantly lowered fertility (Zohary \& Nur, 1959; Stebbins, 1971; Grant, 1981; Richard et al., 1995; Norrmann et al., 1997). However, in a surprising number of species, some individuals with odd-numbered ploidy levels, e.g. pentaploids in Holcus mollis (Jones, 1958; Jones \& Carroll, 1962), triploids in Dactylis glomerata (Zohary \& Nur, 1959; Borrill, 1978), enneaploids ( $9 x$ ) in Andropogon gerardii (Norrmann et al., 1997) have good fertility, linking the ploidy series into an evolutionary whole (Jackson, 1976; Lumaret, 1988a; Thompson \& Lumaret, 1992).

Secondly, from a pragmatic identification standpoint, many ploidy levels are not recognizable as distinguishable separate taxa. So long as polyploids are recurrently created as multiple events, whether allo- or autopolyploid, there is going to be a range of characters that do not lend themselves to distinguishing ploidy levels easily. In some cases this has been carefully studied, e.g. Dactylis (Stebbins \& Zohary, 1959), Anthoxanthum odoratum, (Hedberg, 1967), and Deschampsia (Rothera \& Davy, 1986).

Stebbins \& Zohary (1959) summarize the problem succinctly:

. . the evolutionary relationships within Dactylis would be reasonably well expressed by only two ways of recognizing species. One would be to recognize a single tetraploid and one or two diploid species ... [but . . . the only absolute criterion which separates all diploids from all tetraploids is the chromosome number. The separation of Dactylis into two such variable and similar species is not only impractical from a taxonomic point of view, but is also not altogether compatible with a species concept based upon reproductive isolation.

Thus, they reduce the diploid and tetraploid forms to subspecific status. It is a clear reflection on the reality of gene flow and morphological variation in the complex that the many subsequent workers have largely accepted the merging of eleven diploid taxa, two to five tetraploid taxa and one hexaploid taxon into one named species, Dactylis glomerata (e.g. references cited below). 
Given that some polyploid complexes are considered intraspecific because the ploidy levels are neither morphologically nor genetically discrete, it is important to consider what this might tell us about the population ecology of grasses. I will describe two well-studied examples.

Dactylis glomerata L., cocksfoot, orchard grass, is a rhizomatous grass naturally distributed throughout Europe to northern Africa and Asia that has been widely introduced elsewhere in the world (Müntzing, 1937; Myers, 1941; Stebbins \& Zohary, 1959; Zohary \& Nur, 1959; Borrill, 1961, 1978; Parker \& Borrill, 1968; Lumaret et al., 1987; Lumaret, 1988b; Bretagnolle \& Thompson, 1996). Diploid, tetraploid, and hexaploid plants and populations are known. The diploids are narrowly distributed and often readily distinguished from each other morphologically (Parker \& Borrill, 1968; Lumaret, 1988b). They hybridize to some degree with each other and the diploid hybrids are fertile, although less so than the parents (Borrill, 1961, 1978). Tetraploids in this complex are more abundant and more widespread than the diploids. In many cases (Stebbins \& Zohary, 1959; Borrill, 1961) they cannot be readily distinguished from diploids occurring in the same area. Furthermore, tetraploids are fully interfertile (Stebbins \& Zohary, 1959). Where diploids and tetraploids occur together, natural triploids form. Triploids have about $1 \%$ fertility and are responsible for gene flow between the ploidy levels (Zohary \& Nur, 1959). As noted above, the complexity of the group led Stebbins \& Zohary (1959) to classify all the recognizable types as simply subspecies of Dactylis glomerata.

A detailed study looking for microhabitat differences in northern Spain found local tetraploids to be distributed more broadly than diploids, but particularly they inhabited open and disturbed habitats, whereas the corresponding diploids were confined to shaded areas (Lumaret et al., 1987). Experimental studies indicated that the correlation with shade resulted from the moister conditions under the trees, rather than shade tolerance (Lumaret et al., 1987). The picture was complicated by the presence of tetraploids of subspecies Dactylis glomerata glomerata which escapes from cultivation and had hybridized with local (Galician) tetraploids. Plants of subspecies glomerata and Galacian tetraploids were concentrated in different habitats and their hybrid was found in between them (Lumaret et al. 1987; Fig. 7.1A). The outcome of the extensive study of Dactylis is a picture of a taxon in which local plants form autopolyploids fairly frequently, but diploids can form interspecific hybrids occasionally, the tetraploids are interfertile, and triploids hybridize with tetraploids and other triploids. Thus gene flow links the complex at many points. The variation in the tetraploids matches that of diploids in their areas of origin, but 


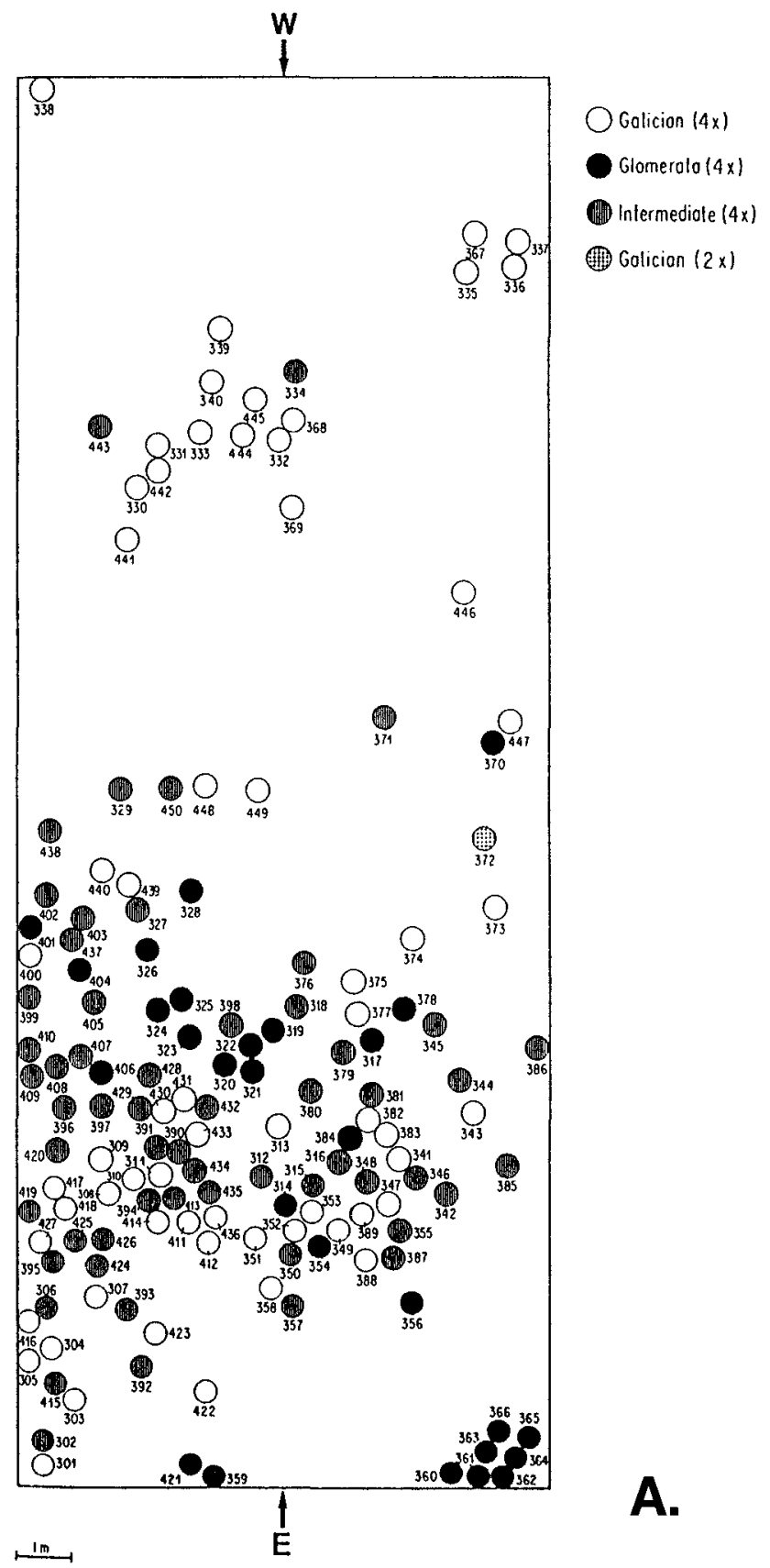

Fig. 7.1. Spatial distribution of polyploids within populations. (A) Dactylis glomerata (fig 5 from Lumaret et al., 1987). The diploid and tetraploid morphs are mapped. (Reproduced with permission of Springer-Verlag.) 


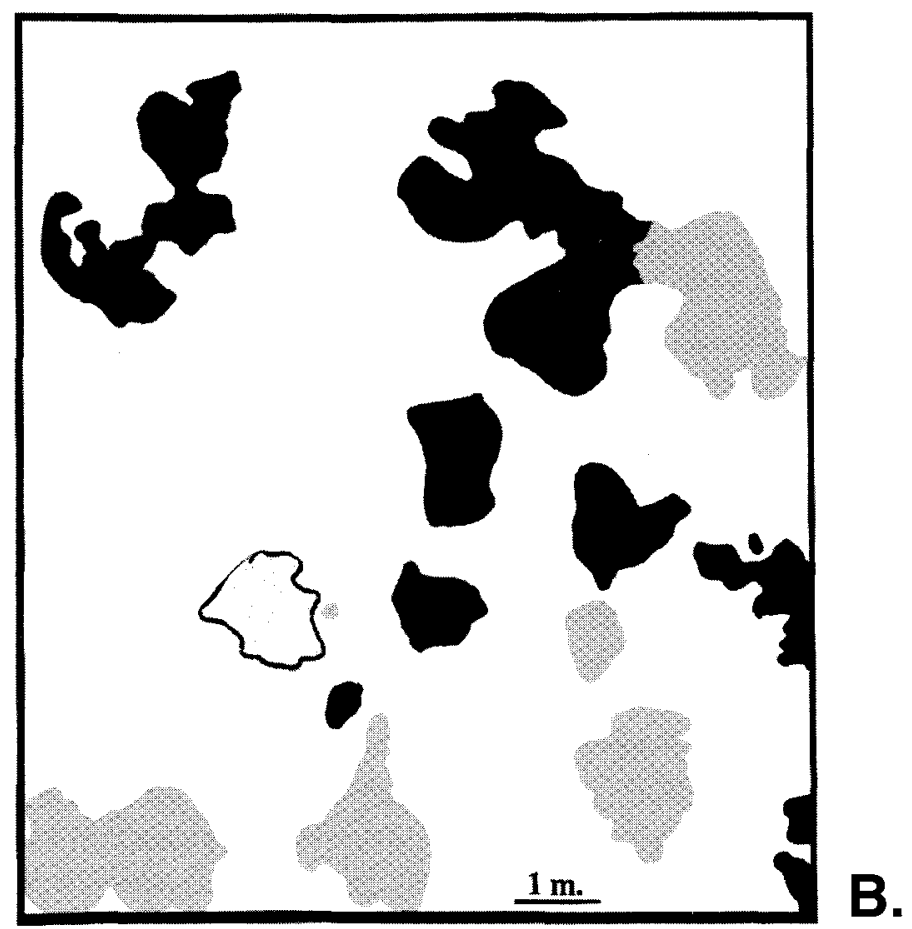

Fig. 7.1. (cont.)

(B) Andropogon gerardii (K. H. Keeler unpublished) population in Boulder Co., CO. Shaded are $A$. gerardii individuals: dark, 60 chromosomes; light, 90 chromosomes; outline intermediate value (probable aneuploid).

overall exceeds that of diploids, because although there is some increase in variation with chromosomal increase, the greater genetic variation is also a result of the multiple origins of tetraploids and their hybridization with each other (Lumaret, 1988b).

Panicum virgatum, switchgrass, is a tall rhizomatous perennial of central North America. A polyploid series was recognized by Nielsen (1944): $2 n=18,36,54,72,90,108$. He found no geographic patterns and in one population the complete range of cytotypes were present. Comparing the morphological characteristics of agronomic potential between the cytotypes, Nielsen (1944) found no consistent differences or any reason to prefer higher polyploids as forage grasses. McMillan \& Weiler (1959) conducted a study of the central USA and again found multiple cytotypes within populations (although none with more than three cytotypes). They too found no consistent pattern for characters they compared between cytotypes (e.g. date of first flowering, height). They reported that clones from one region 
were more similar to clones of the other ploidy levels found in that area, than to the same ploidy level found elsewhere. In Oklahoma and Kansas, Panicum virgatum has two distinct morphotypes that are described as 'lowland' and 'upland' forms. A series of studies (Porter, 1966; Barnett \& Carver, 1967; Brunken \& Estes, 1975) found the lowland form, which is conspicuously taller, more robust and more clumped, to be tetraploid, while the upland form was both hexaploid or octoploid, often equally frequently. Recent studies indicate that this pattern does not hold across the range: upland forms from Nebraska included tetraploids (Hultquist, Vogel \& Kaeppler, 1996; Hultquist et al., 1997), which led Hultquist et al. (1997) to suggest separate origins of the two forms and an autopolyploid series within the upland race, something suggested by Brunken \& Estes (1975) from much less detailed information. Hybridization between the upland and lowland races has not been reported in the literature but can occur $(\mathrm{K}$. P. Vogel \& J. Martinez Reyna, unpublished data).

Thus, in Panicum virgatum there is widespread and significant chromosomal and morphological variation, with a strong geographic component to both cytotype and morphology, but apparently with no simple relationship between them. Despite extensive study, however, there are many regions in which $P$. virgatum has not been analysed and which may clarify the situation. While the details of the polyploid complexes within Dactylis glomerata and Panicum virgatum differ greatly, one could conclude that both species show important and widespread cytotypic and morphological variation which are not related in any simple manner. Both taxa suggest that, whether or not intraspecific polyploidy is adaptive, it is evolving independently of morphology.

\section{Population ecology of intraspecific polyploidy}

As discussed above, there is usually gene flow between the cytotypes in a grass population with several ploidy levels. In Dactylis glomerata, for example, diploids and tetraploids produced viable hybrids at a frequency of at least 3 triploids per 2000 plants. While the triploids were largely pollensterile, they produced viable seeds, including tetraploids and pentaploids (Zohary \& Nur, 1959; Lumaret \& Barrientos, 1990). Thus, genes from the diploids could move via triploids into tetraploid populations. In the case of Zohary \& Nur's study, this logical argument was supported by the presence of B chromosomes in the progeny of the triploids, because in the Israeli populations studied, B chromosomes were found only in diploid plants. Similarly inter-cytotype $(6 x \times 9 x)$ hybrids of Andropogon gerardii form a 
potential bridge between the ploidy levels of that species because they have some pollen and seed fertility, despite being largely aneuploid (Norrmann et al. 1997).

The genetic complexity of some populations can hardly be overemphasized. Nielsen (1944) found five ploidy levels within a single population of Panicum virgatum, and populations with three cytotypes were common (McMillan \& Weiler, 1959). Lumaret et al. (1987) mapped Dactylis glomerata plants with a plot of $10 \times 80 \mathrm{~m}$ that had a local diploid and tetraploid cytotype and an agronomically introduced tetraploid cytotype and the tetraploid hybrids of the two tetraploid races (Fig. 7.1A). Andropogon gerardii also has populations with plants of different ploidy levels intermingling (Keeler 1992, Fig. 7.1B). Because these cytotypes are interfertile, all contribute to the evolutionary population.

When the species-wide variation is considered, many grass species are very complex indeed. Over its range, $D$. glomerata has a very wide variety of cytotypes, genotypes and phenotypes, occurring as single or multiple cytotype populations (Lumaret 1988b; Lumaret \& Barrientos, 1990). The diploid:tetraploid:pentaploid complex of Holcus mollis $\times H$. lanatus likewise has regional differences superimposed on the local populations that contain varying combinations of cytotypes (Jones, 1958; Richard et al., 1995). Others that have not been as intensely studied are likely to be very complex as well, e.g. Bouteloua curtipendula (Gould \& Kapadia, 1962; Kapadia \& Gould, 1964), Poa pratensis, Phragmites australis (Table 7.2).

For most intraspecific polyploid complexes studied, ploidy levels cannot be distinguished at the individual level with sufficient accuracy for taxonomic distinctions (Hedberg, 1967; Rothera \& Davy 1986; Norrmann et al., 1997). Populations of different ploidy levels often differ, but there is such extensive overlap, especially by the higher ploidy levels, that individuals are difficult to categorize. Generally this is a result of the broader variation in the higher ploidy levels (Stebbins 1947, 1971; Hedberg, 1967; Rothera \& Davy, 1986). To the degree that selection acts on the phenotype, not the genotype, such cytotypic variation is cryptic variation, invisible to selection.

\section{Ecological and geographic differentiation}

Except for their impact on speciation, the evolutionary and population biology consequences of polyploidy and intraspecific polyploidy are largely unexplored. Intraspecific polyploid complexes could, like any form of genetic variation, be, for example, adaptive, deleterious, neutral or transient. 
Some differences between ploidy levels seem as if they should be subject to selection. Hedberg (1967) found that tetraploid plants of Anthoxanthum odoratum had hairier leaves, leaf sheaths and glumes than diploids, but the occasional glabrous tetraploid eliminated that for use as a distinguishing character. Diploids on the whole also had smaller spikelets and pollen, but the overlap again precluded using these characters diagnostically. Rothera \& Davy (1986) found that tetraploid Deschampsia caespitosa often, but not always, had larger florets than diploids. This and other characters formed a general syndrome that distinguished diploids and tetraploids, but it broke down for individual plants. Enneaploid $(9 x)$ Andropogon gerardii are usually taller than hexaploids $(6 x)$, but there is so much phenotypic plasticity that the difference is detectable only statistically within populations, not for individuals (K. Keeler, unpublished). Differences in winter-hardiness and growth rate to flowering have been reported in Dactylis (e.g. Bretagnolle \& Thompson, 1996). Other differences have been correlated with ploidy level (e.g. Stebbins, 1971; Lewis, 1980; Grant, 1981; Roy \& Lumaret, 1987; Warner, Ku \& Edwards, 1987, Masterson, 1994). Without a series of direct experiments, it is difficult to judge whether the ploidy levels respond differently enough to stresses in the environment to show different relative fitnesses: although the types of differences suggest they do, the lack of consistent responses within these polyploid complexes argue they do not.

Small-scale ecological differences occur between ploidy levels in Dactylis glomerata (Lumaret et al., 1987; Bretagnolle \& Thompson, 1996); the Holcus lanatus - Holcus molis complex (Richard et al., 1995), Paspalum hexastachyum (Quarín \& Hanna, 1980), Agrostis stolonifera (Kik, Linder \& Bijlsma, 1992), and Anthoxanthum odoratum (Hedberg, 1967). Small-scale ecological differentiation was not found among cytotypes of Deschampsia cespitosa (Rothera \& Davy, 1986) or Andropogon gerardii (Keeler, 1990, 1992). For Panicum virgatum, the situation appears to vary across its range (Nielsen, 1944; McMillan \& Weiler, 1959; Porter, 1966; Barnett \& Carver, 1967; Brunken \& Estes, 1975; Hultquist et al., 1996, 1997).

If the cytotypes cannot be morphologically distinguished in any reliable way, yet can be shown to have distributions correlated with environmental variables, the ecological patterns presumably stem from the fine differences resulting from doubling of the genome, although experiments are needed to eliminate the possibility that the pattern is a stochastic artifact. In Dactylis glomerata there is sufficient data to suggest that patterns are deterministic not random (Stebbins \& Zohary, 1959; Lumaret et al., 1987; Roy \& Lumaret, 1987; Bretagnolle \& Thompson, 1996), while for Andropogon 
gerardii, the lack of match between patterns at different scales (Keeler et al., 1987; Keeler, 1990, 1992) could reasonably result from stochastic effects.

Small-scale maps often reveal intimate mixing of cytotypes (Fig. $7.1 A, B)$, whether or not the species shows ecological differentiation. For Dactylis, levels of mixing vary greatly across its range (Lumaret, 1988b). Andropogon gerardii is mainly hexaploid in the eastern part of its extensive range, but the populations in the west have roughly equal frequencies of 60 and 90 chromosome plants, thoroughly intermingled (Keeler et al., 1987; Keeler, 1990, 1992, unpublished data, Fig. 7.1B). Mixing of the cytotypes of Anthoxanthum odoratum has been enhanced by human activities (Hedberg, 1967). Panicum virgatum populations are usually a mix of cytotypes (Nielsen, 1944; McMillan \& Weiler, 1959), but there is ecological separation as well (e.g. Porter, 1966). Holcus lanatus in France shows both ecological and geographic differences among cytotypes (Richard et al., 1995).

The simplest of the consequences of multiple cytotypes within populations is that a wide array of morphologies and ecological adaptations are available within the complex. Lumaret et al. (1987) demonstrate the power of cytotypic variation (Fig. 7.1A), in the sense that one evolutionary unit (Dactylis glomerata sensu lato) occupies three microhabitats. Given the ecological importance of grasses (they are after all the only plant family with a major ecosystem named for them, and that ecosystem occupies every continent except Antarctica), the ecological differentiation afforded by polyploid complexes deserves to be looked at as a potential adaptive strategy. Much work needs to be done to understand the implication of these consequences of polyploidy to mixed populations and to adaptive evolution of grasses. Andropogon gerardii, for example, is an ecosystem dominant despite cytotypic variation that should lower fitness (Keeler, 1990; Norrmann et al., 1997) (Fig. 7.2). A frequently burned prairie in what is now the 'corn belt' was a virtual monoculture of $A$. gerardii, with more than $80 \%$ of the biomass from this single species (Weaver, 1954). In the face of arguments that 'nature abhors a monoculture' one is moved to ask whether ploidal variation may have helped ameliorate the disadvantages of a monoculture (e.g. lack of genetic variation to resist diseases), facilitating ecological dominance by a single lineage.

Other important points in the population ecology of intraspecific polyploidy are illustrated in Holcus (Jones, 1958; Richard et al., 1995), Anthoxanthum (Hedberg, 1967), Dactylis (Lumaret 1988b), and Panicum (Hultquist et al., 1996, 1997), where in all cases there are inconsistencies in the breeding relationships and behaviour of cytotypes (such as hybridization 


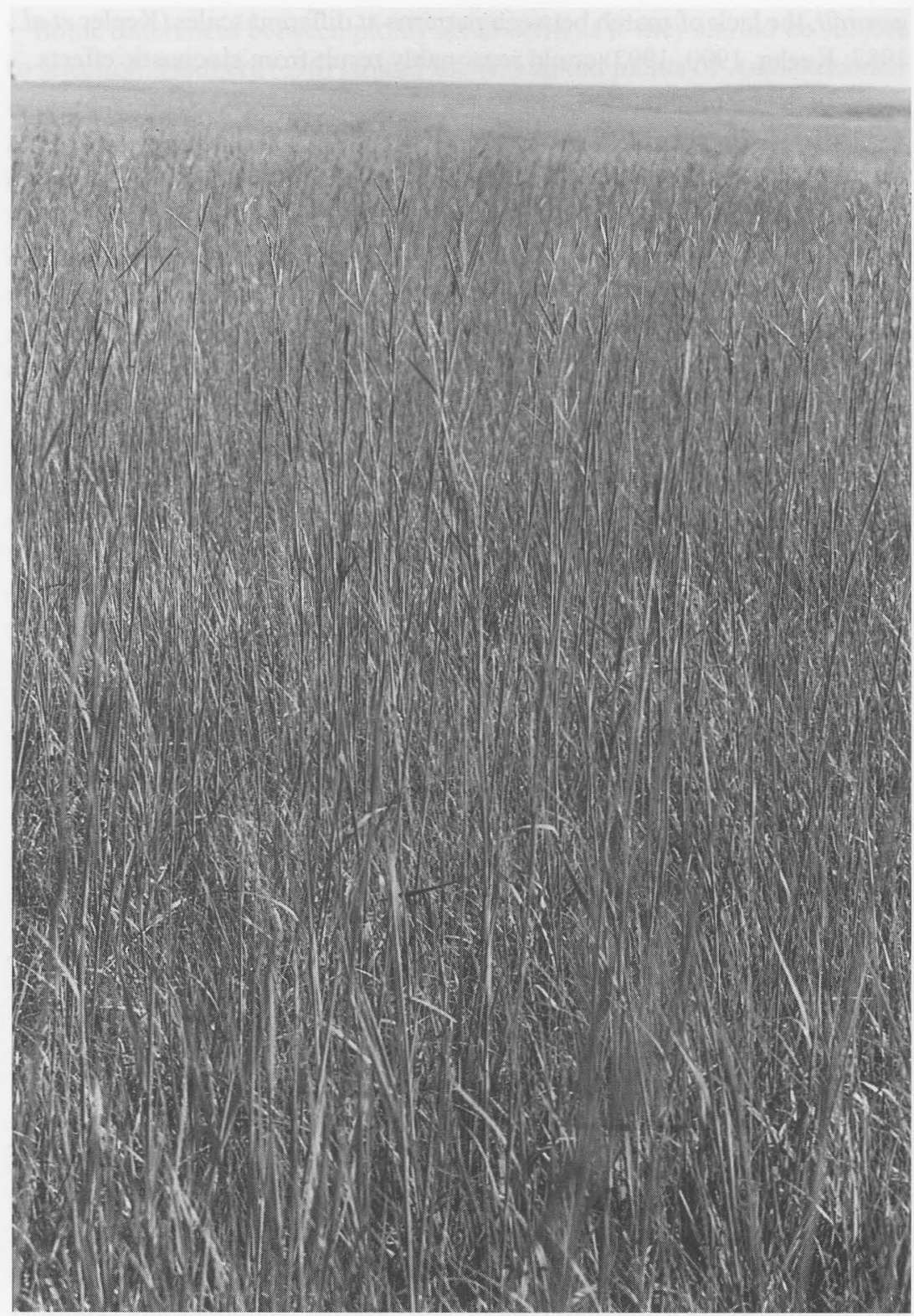

Fig. 7.2. Photo of A. gerardii -dominated prairie (Konza Prairie, Manhattan, KS). Photo by K. H. Keeler 
and genetic composition of populations) in different parts of the species' range. This is understandable given the recurrent formation of auto- and allopolyploids, and backcrossing within the complex. It does, however, mean that caution must be used in extrapolating experimental results across the geographic range of a polyploid complex.

The taxon cycle of Stebbins (1947) provides a description of reality but begs the question of causation. What are the forces that increase ploidy level and allow higher ploidy levels to survive (cf. Levin, 1983; Fowler \& Levin, 1984; Rodríguez, 1996a, b)? Are taxa found at different places in Stebbins' progression simply because of different periods since they originated, or is polyploidy adaptive in some contexts but not in others?

Polyploids have been described as being more variable than diploids (see above). Their differences result from the hybrid origin of allopolyploids or the multiple origin of autopolyploids in different local populations, which must produce selective advantage under some conditions. Other differences ascribed to polyploidy include loss of the incompatibility systems of diploids or other means of greater reproductive promiscuity (Lumaret, 1988a,b; Bretagnolle \& Thompson, 1995). In several Paspalum species, diploids are obligate outcrossers but autotetraploids are largely apomictic (Quarín \& Hanna, 1980; Quarín, Hanna \& Fernández, 1982).

It seems unlikely that all or even most grass species with intrapopulation polyploidy will have the same fitness relationships among the cytotypes, but it is reasonable to expect that there are a finite number of combinations of genetics and ecology which select for (or permit) the realized distribution of cytotypes. Given the importance of grasses, both ecologically and economically, and the frequency of intraspecific polyploidy (Tables 7.2, 7.3), the evolutionary forces underlying intraspecific polyploidy present a rich area for future research.

\section{Summary}

Polyploid series within local populations occur in many grass species. The evidence suggests recurring autopolyploidy is often the cause of the polyploid variation, but recurrent allopolyploidy is indicated in some cases. Often the different ploidy levels cannot be distinguished morphologically and they exchange genes at least occasionally; thus the evolutionary unit is a cytologically complex population. The implications of the presence of multiple cytotypes for local adaptation have scarcely begun to be investigated. 


\section{Acknowledgements}

This work was supported in part by NSF 95-09139 and a University of Nebraska faculty research leave. It is dedicated to G. L. Stebbins.

\section{References}

Ainouche, M., Misset, M-T, \& Huon, A. (1995). Genetic diversity in Mediterranean diploid and tetraploid Bromus L. (section Bromus Sm.) populations. Genome, 38, 879-88.

Al-Janabi, S. M., Honeycutt, R. J., McClelland, M., and Sobral, B. W. S. (1993). A genetic linkage map of Saccharum spontaneum L. 'SES 208'. Genetics. 14, 1249-60.

Barnett, F. L. \& Carver, R. F. (1967). Meiosis and pollen stainability in switchgrass, Panicum virgatum L. Crop Science, 7, 301-4.

Bever, J. D. \& Felber, F. (1993). The theoretical population genetics of autopolyploidy. Oxford Surveys in Evolutionary Biology, 8: 185-217.

Björkman, S. O. (1984). Chromosome studies in Agrostis. II. Hereditas, 40, 254-68.

Borrill, M. (1961). The pattern of morphological variation in diploid and tetraploid Dactylis. Journal of the Linnean Society (Botany), 56, 441-52.

Borrill, M. (1978). Evolution and genetic resources in cocksfoot. Report of the Welsh Plant Breeding Station (Aberystwyth, Wales) pp. 190-209.

Bowden, W. M. (1965). Chromosome numbers and taxonomic notes on some northern grasses. III. Twenty five genera. Canadian Journal of Botany. 38, 541-57.

Bretagnolle, F. \& Thompson, J. D. (1995). Gametes with the somatic chromosome number: mechanisms for their formation and role in the evolution of autopolyploid plants. New Phytologist., 129, 1-22.

Bretagnolle, F. \& Thompson, J. D. (1996). An experimental study of ecological differences in winter growth between sympatric diploid and autotetraploid Dactylis glomerata. Journal of Ecology, 84, 343-51.

Brockman, C. \& Elven, R. (1992). Ecological and genetic consequences of polyploidy in arctic Draba (Brassicaceae). Evolutionary Trends in Plants, 6, $111-24$.

Brown, W. V. (1950). A cytological study of some Texas Gramineae. Bulletin of the Torrey Botanical Club. 77, 63-76.

Brunken, J. N. \& Estes, J. R. (1975) Cytological and morphological variation in Panicum virgatum L. The Southwestern Naturalist, 19, 379-85.

Burton, G. W. (1942). A cytological study of some species in the tribe Panicaceae. American Journal of Botany, 29, 355-9.

Campbell, C. S., Greene, G. W. \& Bergquist, S. E. (1987). Apomixis and sexuality in three species of amelanchier, shadbush (Rosaceae, Maloideae). American Journal of Botany, 74, 321-8.

Church, G. L. (1936). Cytological studies in the Gramineae. American Journal of Botany, 23, 12-16.

Dunford, M. P. (1985). A statistical analysis of morphological variation in cytotypes of Atriplex canescens (Chenopodiaceae) The Southwestern Naturalist, 30, 377-81.

Ehlke, N. J. \& Hill, R. R., Jr. (1988). Quantitative genetics of allotetraploid and allopolyploid populations. Genome, 30: 63-69. 
Federov, V. (1974). Chromosome Numbers of Flowering Plants. West Germany: O. Koeltz Science Publishers.

Fisher, R. A. (1949). The Theory of Inbreeding. New York: Academic Press.

Fowler, N. L. \& Levin, D. A. (1984). Ecological constraints on the establishment of a novel polyploid in competition with its diploid progenitor. American Naturalist, 124, 703-11.

Freeman, D. C. \& McArthur, E. D. (1989). Atriplex canescens. CRC Handbook of Flowering Plants. VI. pp. 75-86. Boca Raton, FL: CRC Press.

Fults, J. L. (1942) Somatic chromosome numbers in Bouteloua. American Journal of Botany, 29, 45-56.

Goldblatt, P. (1980). Polyploidy in Angiosperms: Monocotyledons. In Polyploidy: Biological relevance, ed. W. H. Lewis. New York: Plenum. pp. 219-41.

Gould, F. W. (1958). Chromosome numbers in southwest grasses. American Journal of Botany, 10: 757-86.

Gould, F. W. \& Kapadia, Z. J. (1962). Biosystematic studies in the Bouteloua curtipendula complex. I. The aneuploid rhizomatous $B$. curtipendula of Texas. American Journal of Botany, 49, 887-92.

Grant, J. E., Brown, A. D. H. \& Grace, J. P. (1984). Cytogenetic and isozyme diversity in Glycine tomentella Hayata (Leguminosae). Australian Journal of Botany, 32, 655-63.

Grant, V. (1981). Plant speciation. 2nd edition. New York: Columbia University Press.

Gu, M.-H., Ma, H.-T. \& Liang, G. H. (1984). Karyotype analysis of seven species in the genus Sorghum. The Joumal of Heredity, 75, 196-202.

Guenegou, M. C., Citharel, J. \& Levasseur, J. E. (1988). The hybrid status of Spartina anglica (Poaceae). Enzymatic analysis of the species and of the presumed parents. Canadian Journal of Botany, 66, 1830-3.

Haldane, J. B. S. (1930). Theoretical genetics of autopolyploids. Journal of Genetics. 22, 359-72.

Harlan, J. R. (1949). Apomixis in side-oats grama. American Journal of Botany, 36, 495-9.

Hansen, A. A. \& Hill, H. D. (1953). The occurrence of aneuploidy in Phalaris sp. Bulletin of the Torrey Botanical Club, 80, 172-6.

Hedberg, I. (1967). Cytotaxonomic studies on Anthoxanthum odoratum L s. lat. II/ Investigations of some Swedish and a few Swiss population samples. Symbolae Botanicae Upsalienses, 18, 1-88.

Hickman, J. C. (ed.) (1993). The Jepson Manual of the Higher Plants of California. Berkeley: University of California Press.

Hultquist, S. J., Vogel, K. P., \& Kaeppler, S. (1996). Chloroplast DNA and nuclear DNA content variation among cultivars of switchgrasses Panicum virgatum L. Crop Science, 36, 1049-52.

Hultquist, S. J., Vogel, K. P., Lee, D. J, Arumuganathan, K. \& Kaeppler, S. (1997). DNA content and chloroplast DNA polymorphisms among switchgrasses from remnant midwestern prairies. Crop Science, 37 , in press.

Hymowitz, T., Parker, R. G. \& Singh, R. J. (1991). Cytogenetics of the genus Glycine. In Chromosome Engineering in Plants, ed. T. Tsuchiye \& P. K. Gupta, pp. 53- 81. New York: Elsevier.

Jackson, R. C. (1976). Evolutionary and systematic significance of polyploidy. Annual Review of Ecology and Systematics, 7, 209-34.

Jackson, R. C. (1982). Polyploidy and diploidy: new perspectives on chromosome pairing and its evolutionary implications. American Journal of Botany, 69: $1512-1523$. 
Jones, K. (1958). Cytotaxonomic studies in Holcus I. The chromosome complex of Holcus mollis L. New Phytologist, 57, 191-210.

Jones, K. \& Carroll, C. P. (1962). Cytotaxonomic studies in Holcus. II. Morphological relationships in Holcus mollis L. New Phytologist, 61, 63-71.

Kankanpää, J., Mannonen, L. \& Schulman, A. L. (1996). The genome sizes of Hordeum species show considerable variation. Genome, 39, 730-5.

Kapadia, Z. J. \& Gould, F. W. (1964). Biosystematic studies in the Bouteloua curtipendula complex. III. Pollen size as related to chromosome numbers. American Journal of Botany, 51, 166-72.

Keeler, K. H. (1990). Distribution of polyploid polymorphism in big bluestem, Andropogon gerardii in the tallgrass prairie region. Genome, 33, 95-100.

Keeler, K. H. (1992). Local polyploid variation in the native prairie grass Andropogon gerardii. American Journal of Botany, 79, 1229-32.

Keeler, K. H. \& Kwankin, B. (1989). Polyploid polymorphism in prairie grasses. In Plant population biology, ed. J. H. Bock \& Y. B. Linhart, pp. 99-128. Boulder CO: Westview Press.

Keeler, K. H., Kwankin, B., Barnes, P. W. \& Galbraith, D. W. (1987). Polyploid polymorphism in Andropogon gerardii Vitman (Poaceae). Genome, 29, 374-9.

Kik, C., Linder, Th. E., \& Bijlsma, R. (1992). The distribution of cytotypes in ecologically contrasting populations of the clonal perennial Agrostis stolonifera. Evolutionary Trends in Plants, 6, 93-8.

Lewis, W. H. (ed.) (1980). Polyploidy: Biological Relevance. New York: Plenum.

Levin, D. A. (1983). Polyploidy and novelty in flowering plants. The American Naturalist, 122, 1-25.

Lumaret, R. (1988a). Adaptive strategies and ploidy levels. Acta Oecologia/Oecologia Plantarum, 9, 83-93.

Lumaret, R. (1988b). Cytology, genetics and evolution in the genus Dactylis. CRC Critical Reviews of Plant Science, 7, 55-91.

Lumaret, R. \& Barrientos, E. (1990). Phylogenetic relationships and gene flow between sympatric diploid and tetraploid plants of Dactylis glomerata (Gramineae). Plant Systematics and Evolution, 169, 81-96.

Lumaret R., Guillerm, J-L, Delay, J., Loutfi, A. L., Izco, J. \& Jay, J. (1987). Polyploidy and habitat differentiation in Dactylis glomerata L. from Galicia (Spain). Oecologia (Berlin), 73, 436-46.

Masterson, J. (1994). Stomatal size in fossil plants: evidence for polyploidy in majority of Angiosperms. Science, 264, 421-4.

Mather, K. (1936). Segregation and linkage in autotetraploids. Journal of Genetics, 32, 287-314.

McMillan, C. \& Weiler, J. (1959). Cytogeography of Panicum virgatum in central North America. American Journal of Botany, 46, 590-3.

Müntzing, A. (1937). The effects of chromosomal variation in Dactylis. Hereditas, 29, 113-235.

Myers, W. M. (1941). Genetic consequences of chromosomal behavior in orchard grass Dactylis glomerata L. Journal of the American Society of Agronomists, 33, 893-900.

Myers, W. M. (1947). Cytogenetics and genetics of forage grasses. The Botanical Gazette, 6, 319-421.

Myers, W. M. \& Hill, H. D. (1947). Distribution and nature of polyploidy in Festuca elatior L. Bulletin of the Torrey Botanical Club, 2, 99-111.

Nielsen, E. L. (1939). Grass studies III. Additional somatic chromosome complements. American Journal of Botany, 26, 366-72.

Nielsen, E. L. (1944). Analysis of variation in Panicum virgatum. Journal of Agricultural Research, 69, 327-53. 
Nielsen, E. L. \& Humphrey, L. M. (1937) Grass studies I. Chromosome numbers in certain members of the tribes Festuceae, Hordeae, Aveneae, Agrostideae, Chlorideae, Phalaridaceae and Tripsaceae. American Journal of Botany, 24, $276-9$.

Norrmann, G. A. \& Quarín, C. L. (1987). Permanent odd polyploidy in a grass (Andropogon ternatus). Genome, 29, 340-4.

Norrmann, G. A, Quarín, C. L., \& Burson, B. L. (1989). Cytogenetics and reproductive behavior of different chromosome races in six Paspalum species. Journal of Heredity, 80, 24-8.

Norrmann, G. A, Quarín, C. L., \& Keeler, K. H. (1997) Evolutionary implications of meiotic chromosome behavior, reproductive biology and hybridization in $6 x$ and $9 x$ cytotypes of Andropogon gerardii (Poaceae), American Journal of Botany, 84, 201-7.

Panje, R. R. \& Babu, C. N. (1960). Studies in Saccharum spontaneum distribution and geographic association of chromosome numbers. Cytologia, 25, 152-72.

Parker, P. F. \& Borrill, M. (1968). Studies on Dactylis I. Fertility relationships in some diploid subspecies. New Phytologist, 67, 649-62.

Porter, C. L. Jr. (1966). An analysis of variance between upland and lowland switchgrass, Panicum virgatum L. Ecology, 47, 980-92.

Quarín, C. L., \& Hanna, W. W. (1980). The effect of three ploidy levels on meiosis and mode of reproduction in Paspalum hexastachyum. Crop Science, 20, 69-75.

Quarín, C.L., Hanna, W.W. \& Fernández, A. (1982). Genetic studies in diploid and tetraploid Paspalum species. The Journal of Heredity, 76, 2546.

Richard, M., Jubier, M-F., Bajon, R., Gouyon, P-H. \& Lejeune, B. (1995). A new hypothesis for the origin of pentaploid Holcus from diploid Holcus lanatus L. and tetraploid Holcus mollis L. in France. Molecular Evolution, 4, $29-38$.

Rodríguez, D. J. (1996a). A model for establishment of polyploidy in plants. American Naturalist, 147, 3346.

Rodríguez, D. J. (1996b). A model for the establishment of polyploidy in plants: viable but infertile hybrids, iteroparity, and demographic stochasticity. Journal of Theoretical Biology, 180, 189-96.

Rothera S. L. \& Davy, A. J. (1986). Polyploidy and habitat differentiation in Deschampsia caespitosa. New Phytologist, 102, 449-67.

Roy, J. \& Lumaret, R. (1987). Associated clinal variation in leaf tissue water relations and allozyme polymorphism in Dactylis glomerata L. populations. Evolutionary Trends in Plants, 1, 9-19.

Sadasivaiah, R. S. \& Weijer, J. (1981). The origin and meiotic behaviour of hexaploid northern wheatgrass (Agropyron dasystachyum). Chromosoma (Berl.), 82, 121-32.

Seal, A. G. (1983). DNA variation in Festuca. Heredity, 50, 225-36.

Sears, E. R. (1969). Wheat cytogenetics. Annual Review of Genetics, 3, 451-68.

Seberg, O. \& von Bothmer, R. (1991). Genome analysis of Elymus angulatus and E. patagonicus (Poaceae) and their hybrids in North and South American Hordeum spp. Plant Systematics and Evolution, 174, 75-82.

Simmonds, N. W. (1976). Evolution of Crop Plants. London: Longman.

Snyder, L. A. \& Harlan, J. R. (1953). A cytological study of Bouteloua gracilis from western Texas and eastern New Mexico. American Journal of Botany, 40, $702-7$.

Stebbins, G. L. (1947). Types of polyploidy I. Their classification and significance. Advances in Genetics, 1, 403-29.

Stebbins, G. L. (1971). Chromosomal Evolution in Higher Plants, Reading, MA: Addison-Wesley. 
Stebbins, G. L. \& Zohary, D. (1959). Cytogenetic and evolutionary studies in the genus Dactylis I. Morphology, distribution, and interrelationships of the diploid subspecies. University of California Publications in Botany, 31, 1-40.

Sutherland, D. (1986). Poaceae, Barnh., the grass family. In Flora of the Great Plains. Great Plains Flora Association. pp. 1113-235. Lawrence KS: University Presses of Kansas.

Thompson, J. D. \& Lumaret, R. (1992). The evolutionary dynamics of polyploid plants: origin, establishment and persistence. Trends in Ecology and Evolution, 7, 302-7.

Tsuchiye, T. \& Gupta, P. K. (eds.) (1991). Chromosome Engineering in Plants. New York: Elsevier.

von Bothmer, R. \& Jacobsen, N. (1986). Interspecific crosses in Hordeum (Poaceae). Plant Systematics and Evolution, 153, 4964.

Warner, D. A., Ku, M. S. B., \& Edwards, G. E. (1987). Photosynthesis, leaf anatomy, and cellular constituents in the polyploid C4 grass Panicum virgatum. Plant Physiology, 84, 461-6.

Weaver, J. E. (1954). North American Prairie. Lincoln NE: Johnsen.

Zohary, D. \& Nur, U. (1959). Natural triploids in the orchard grass, Dactylis glomerata L. polyploid complex and their significance for gene flow from diploid to tetraploid levels. Evolution, 13, 311-17. 